\title{
POSISI BAHASA ARAB DIDUNIA
}

\section{NUR ENDANG ZAINAL}

Sekolah tinggih agama islam negeri (stain) sorong, papua barat, Indonesia

Jurusan Dakwah/Program Studi Komunikasi Penyiaran Islam

Email:nurzainal0607@gmail.com

\begin{abstract}
Abstarak
Bahasa Arab adalah salah satu bahasa tertua di dunia. Ada beberapa teori yang menjelaskan tentang awal mula munculnya bahasa Arab. Teori pertama menyebutkan bahwa manusia pertama yang melafalkan bahasa Arab adalah Nabi Adam alaihissalam Analisa yang digunakan; Nabi Adam alaihissalaam (sebelum turun ke bumi) adalah penduduk surga, dan dalam suatu riwayat dikatakan bahwa bahasa penduduk surga adalah bahasa Arab, maka secara otomatis bahasa yang digunakan oleh Nabi Adam alaihissalam adalah bahasa Arab dan tentunya anak-anak keturunan Nabi Adam alaihissalam pun menggunakan bahasa Arab. Setelah jumlah keturunan Nabi Adam alaihissalam bertambah banyak dan tersebar ke pelbagai tempat, bahasa Arab yang digunakan saat itu berkembang menjadi jutaan bahasa yang berbeda. Teori ini kurang populer dikalangan ahli bahasa modern, khususnya di kalangan orientalis, dengan asumsi bahwa tidak ada bukti ilmiah yang menyebutkan bahwa 'Adam menggnakan bahasa arab sebagai bahasa sehari-hari.
\end{abstract}

\section{PENDAHULUAN}

Bahasa arab merupakan bahasa suci al-Qur'an Arab adalah salah satu bahasa tertua di dunia. Ada beberapa teori yang menjelaskan tentang awal mula munculnya bahasa Arab. Teori pertama menyebutkan bahwa manusia pertama yang melafalkan bahasa Arab adalah Nabi Adam'alaihissalâm. Analisa yang digunakan Nabi Adam alaihissalam (sebelum turun ke bumi) adalah penduduk surga, dan dalam suatu riwayat dikatakan bahwa bahasa penduduk surga adalah bahasa Arab, maka secara otomatis bahasa yang digunakan oleh Nabi Adam alaihissalam adalah bahasa Arab dan tentunya anak-anak keturunan Nabi Adam alaihissalam pun menggunakan bahasa Arab. Itulah salah satu sebab bahasa arab menjadi bahasa suci al-Qur'an. 


\section{PERKEMBANGAN BAHASA ARAB DIINDONESIA}

Sejarah perkembangan bahasa Arab di Indonesia dimulai sejak masyarakat Indonesia mulai memeluk Islam. Dalam hal ini bahasa Arab dipelajari semata-mata sebagai alat untuk mempelajari dan memperdalam pengetahuan Islam, baik disurau, masjid, pondok pesantren, maupun madrasah-madrasah. Sejak zaman penjajahan Belanda, banyak sekali mahasiswa Indonesia yang melanjutkan di beberapa perguruan tinggi di Timur Tengah. Mereka pada umumnya, mempelajari bahasa Arab bukan semata-mata sebagai alat, melainkan sebagai tujuan. Karena itu, setelah studi mereka berhasil, banyak diantara mereka yang tergolong ahli bahasa Arab dan mampu menggunakan bahasa Arab secara aktif karena menguasai empat segi kemahiran bahasa : menyimak (mendengar), berbicara, dan menulis.

Setelah mereka pulang ke tanah air, mereka mengusahakan pembaharuan metode untuk pengajaran bahasa Arab. Dengan metode tersebut, mereka berhasil menumbuhkan pengertian bahwa bahasa Arab (Fusha) perlu- untuk tidak menyebut harus- dipelajari juga sebagai tujuan, yakni untuk membentuk ahli-ahli bahasa Arab dan menghasilkan alumni yang mampu menggunakan bahasa Arab secara aktif sebagai alt komunikasi untuk berbagai keperluan. Setelah pengertian dan kesadaran tersebut meluas, para ahli bahasa arab di Indonesia terdorong untuk segera mengajarkan bahasa Arab untuk melalui metode yang waktu itu dianggap terbaru dan paling sesuai agar bahasa Arab dipelajari juga sebagai tujuan (baca: sebagai kebutuhan), selain sebagai alat. Pengertian bahasa Arab dengan metode dan untuk tujuan tersebut sudah mulai dilaksanakan dibeberapa madrasah, baik di Sumatra- seperti madrasah at Thawalib-dan di Jawaseperti pondok Darussalam Gontor (Ponorogo)

Pengajaran bahasa Arab (Fusha) yang dipelajari di Indonesia dimaksudkan untuk mencapai dua tujuan.

Pertama, Sebagai alat untuk mempelajari dan memperdalam pengetahuan Islam seperti di madrasah-madrasah (negeri atau swasta), pondok pesantren, dan Perguruan Tinggi Agama Islam (negeri atau swasta). 
Kedua, sebagai tujuan, yaitu membentuk tenaga-tenaga ahli bahasa arab atau untuk menghasilakan alumni yang mampu menggunakan bahasa Arab secara aktif sebagai alat komunikasi untuk berbagai keperluan.

\section{METODOLOGI PEMBELAJARAN BAHASA ARAB DIINDONESIA}

Secara umum, penerapan metode pembelajaran bahasa Arab yang dikembangkan dipesantren- pesantren dan lembaga pendidikan, termasuk perguruan tinggi Islam masih menitikberatkan pada metode gramatika - terjamah. Ini terbukti dari ciri-ciri khusus yang telah dikembangkan, sebagai berikut.

Pertama, pemberian keterangan kaidah-kaidah tata bahasa oleh para pengajar dan penghafalan kaidah-kaidah tersebut oleh para pelajar

Kedua, penghafalan kata-kata tertentu yang kemudian dirangkaikan menurut kaidah-kaidah tata bahasa yang berlaku.

Ketiga, kegiatan kegiatan menerjemahkan kata demi kata, dan kalimat demi kalimat dari bahasa Arab ke bahasa pelajar dan sangat kurang sebaliknya yakni dari bahasa pelajar ke dalam bahasa Arab.

Keempat, latihan untuk kemahiran menggunakan bahasa secara lisan sangat kurang, kalaupun diberikan, frekuensinya hanyalah sesekali dengan cara-cara yang membosankan karena tidak ada variasi.

Kelima, kurang menggunakan alat peraga atau alat bantu yang dapat didengar-dilihat (audiovisual aids). Gambar yang digunakan bersifat ilustrasi dari pada untuk pengajaran.

Keadaan ini menunjukkan, lulusan lembaga-lembaga pendidikan agama itu masih produk pengajaran bahasa Arab yang didasarkan atas informating approach dan metode gramatika tarjamah. Padahal approach dan metode terhadap kurikulum bersifat disintegrasi, yakni tidak mempunyai hubungan yang erat antara pelajaran bahasa Arab dengan mata ajar lainnya. Mata ajar bahasa Arab dipecah - pecah secara tajam dalam bagian yang terpisah-pisah, sedangkan kemahiran bahasa tidak diberikan. Dengan perkataan lain, pelajaran bahasa Arab disampaikan 
lebih bersifat teoritis karena lebih mengutamakan pembentukan ahli ilmu bahasa, bukan pembentukan manusia yang mampu berbahasa.

\section{KESIMPULAN}

1. Sejarah perkembangan bahasa Arab di Indonesia dimulai sejak masyarakat Indonesia mulai memeluk Islam. Dalam hal ini bahasa Arab dipelajari semata-mata sebagai alat untuk mempelajari dan memperdalam pengetahuan Islam, baik disurau, masjid, pondok pesantren, maupun madrasah-madrasah. Sejak zaman penjajahan Belanda, banyak sekali mahasiswa Indonesia yang melanjutkan di beberapa perguruan tinggi di Timur Tengah. Mereka pada umumnya, mempelajari bahasa Arab bukan semata-mata sebagai alat, melainkan sebagai tujuan. Karena itu, setelah studi mereka berhasil, banyak diantara mereka yang tergolong ahli bahasa Arab dan mampu menggunakan bahasa Arab secara aktif karena menguasai empat segi kemahiran bahasa : menyimak (mendengar), berbicara, dan menulis.

2. Secara umum, penerapan metode pembelajaran bahasa Arab yang dikembangkan dipesantren- pesantren dan lembaga pendidikan, termasuk perguruan tinggi Islam masih menitikberatkan pada metode gramatika - terjamah.

\section{DAFTAR PUSTAKA}

Izzan, Ahmad, 2009, Metodologi Penbelaran Bahasa Arab, Bandung: Humaniora.

Syakur , Nazri, 2010, Revolusi Metodologi Pembelajaran Bahasa Arab, Yogyakarta: BIPA

Chejne, Anwar G.,(1996) Bahasa Arab dan Peranannya dalam Sejarah, terj. Aliudin Mahjudin, Jakarta: Pusat Pembinaan dan Pengembangan Bahasa. 